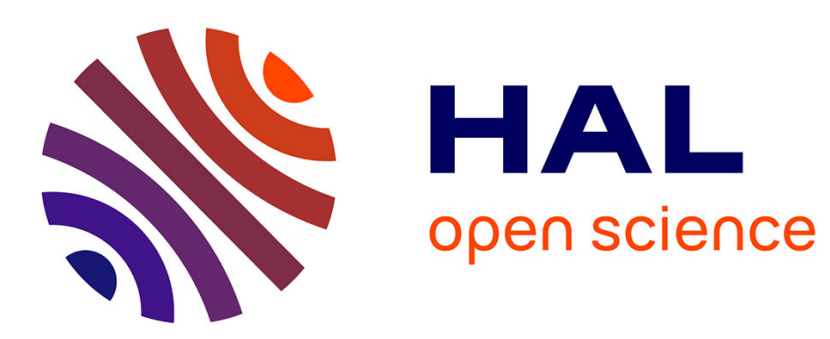

\title{
Social Media or Social Business Networks?
}

\author{
Issam Moghrabi, Abdullah R. Al-Mohammed
}

\section{To cite this version:}

Issam Moghrabi, Abdullah R. Al-Mohammed. Social Media or Social Business Networks?. 15th Conference on e-Business, e-Services and e-Society (I3E), Sep 2016, Swansea, United Kingdom. pp.4252, 10.1007/978-3-319-45234-0_4. hal-01702167

\section{HAL Id: hal-01702167 \\ https://hal.inria.fr/hal-01702167}

Submitted on 6 Feb 2018

HAL is a multi-disciplinary open access archive for the deposit and dissemination of scientific research documents, whether they are published or not. The documents may come from teaching and research institutions in France or abroad, or from public or private research centers.
L'archive ouverte pluridisciplinaire HAL, est destinée au dépôt et à la diffusion de documents scientifiques de niveau recherche, publiés ou non, émanant des établissements d'enseignement et de recherche français ou étrangers, des laboratoires publics ou privés. 


\title{
Social Media or Social Business Networks?
}

\author{
Issam A.R. Moghrabi, Abdullah R. Al-Mohammed \\ \{moughrabi.i, GUST1303102011\} @gust.edu.kw \\ Gulf University for Science and Technology, Mishref, Kuwait
}

\begin{abstract}
Social media has incurred changes that can be seen in developing new customer centric strategies, objectives, and goals, to realigning operations to meet the constantly changing and highly sensitive demands of customers, among others. The increase in value of social media channels is more than just a luxury gateway; rather those channels have become quintessential venues of communication between the customer and the organization. The purpose of this paper is to analyze the effect of social media on the business environment with particular emphasis on how it impacts both the customer and the organization. This will be accomplished through focusing on several facets such as social media and globalization, social media vs. traditional media, bridging the gap between the customer and the organization, and how social media empowers the customer. The paper presents some recommendations and precautions pertinent to the utilization of social nets into the core business processes.
\end{abstract}

Keywords: social media, viral marketing, business networks, online reputation systems.

\section{Introduction}

Social media platforms have become a forum where users can share content and interact with one another. Though the involvement of the word "social" indicates the big role played by the people in sharing their social life on those digital platforms, such platforms are largely becoming business networks or media [1]. They are shaping new business models and moving the market into new prospects. Social media have also shaped the existence of online communities that share common interests and tendencies $[1,2]$.

In the previous decade, organizations have been working by cutting edge levels of data and correspondence. Technology innovations define new methods for communication and socializing. Technology is primarily adopted as a means to decrease the communication barriers. Innovative technology has become an enabler of a new era of communication with a huge impact on business, thus creating new means of interactions and introduced us to a new socializing median called social media [3], [6].

Social media has seized a considerable share of everyday life activities, especially due to the multitude of purposes of social media activities. Therefore, it only makes sense that companies and businesses would decide to take advantage of the benefits offered by social media, and integrate social media within their organizations in order to help them achieve their strategic goals and objectives. Social media had the power to transform organization's business model from operations, marketing, and not end- 
ing with sales. Whether they were small businesses or big operating companies, many businesses nowadays cannot operate without the aid of social networking accounts. In fact social media now is dramatically affecting traditional business-to-customer models as well as business-to-business models [4]. Moreover, since the year 2010, social networking has been regarded the internet buzzword, utilized as as a cultural facilitator as well as a business tool. Social networks are different from the traditional online marketing-channels because they have the ability to gather, parse, and sort valuable demographic data, on daily basis. Social networking includes a variety of services, evolutions and communications that happen in the cyberspace [3] [14]. Social networking has attracted a lot of attention due to its ability to bring together huge customer bases to organizations of all sizes, including the small ones that target niche markets. Social networks have undeniably transformed businesses. The changes in business induced through the incorporation of social media can be seen in developing new customer centric strategies, objectives, and goals, to realigning operations to meet the constantly changing and highly sensitive demands of customers, to the establishment of social media dedicated units and budgets, to bridging the gap between the organization and the customer, to developing an IT infrastructure to meet the demands of such social media units. In addition, it has the potential to empower clients and end users [3] [12]. Further, it has the ability to make customer-metrics more granular. Social networks bring several functionalities. Through business analytics/intelligence, one is able to obtain demographic data, location data, friends and relationships data, real time trends and content, and user-interaction data. The new social media seems to have become the new telephone and/or the new email [1] [9].

The paper is organized as follows: Section 2 addresses the main aim of the paper; Section 3 brings some insight into the issues being addressed here and sheds light on the repercussions of utilizing social media into businesses to create a transformation in the concept of doing business at a price that could be costly to organizations both financially and morally. Section 4 mainly embodies recommendations and precautions related to the adoption of the use of social networks to become the business networks or the social business. Finally, in Section 5, the conclusions are presented.

\section{$2 \quad$ Research Question}

The motivation behind this paper is to explore, investigate, and break down the impact of online networking on the business environment with specific accentuation on how it sways both the client and the association, both positively and negatively. This is done through concentrating on online networking and globalization, online networking versus conventional media, overcoming any issues between the client and the business, how online networking enables the client, which is accomplished at lower expenses and higher scope than customary media. Also, in this paper, we will raise the issue of whether businesses can make due in today's rapidly changing business environment without online networking, and we will be presenting our recommendations on how organizations can best utilize long range social networking to enhance their brand image and achieve higher customer loyalty. The article will also 
be giving guidelines of what entrepreneurs should look at when constructing social marketing strategies [4][13].

The main hypothesis here is that social networks have caused a migration in the business culture and have themselves emerged as business networks. Thus, guidelines need be established as to the adoption of such networks to become an integral part of the business processes.

\section{Some Insight}

We start this section by exploring the impact of social media on the business environment from a) business perspective, and from $b$ ) customer perspective.

From a business perspective, integrating social media inside of a business and aligning it with an organization's strategies and goals has turned out to be less of an alternative, and even more a need in today's aggressive and dynamic business environment. The reason is that organizations must recognize the demands of the global competitive business environment and respond promptly in addition to ensuring that they predict trends in that environment - be proactive [4]. By embracing online social networking, and building up a culture of client centricity supported by the use of the social networking channels, organizations can develop a competitive advantage. This can be achieved by reengineering the organizations primary business functions such as marketing, advertising, public relations, and customer experience management to be driven by and be highly dependent on social media platforms $[4,5]$.

Social media has forced companies to change their infrastructure, influence their strategies, and transform their objectives to include a social media specific target such as obtaining $1 \mathrm{M}$ followers online, create a dedicated social media team, a dedicated budget, and minimize the volume of poor comments which may reflect negatively on the organization's image [4][6].

Furthermore, not only has social media affected business and consumers, but it has also, on a larger scale, affected the economy as a whole by creating new jobs and new job titles, such as social media officers. Moreover, it also created new types of organizations such as social media agencies and consultancy [4].

Looking at Twitter platform, it has given people an opportunity to link with those who are like minded. For instance, business people meet, share ideas and they learn from each other. Using business intelligence and social-media analytics [9], engagingcontent strategy can be formed to monitor interactions that take place within it and detect trends to improve decision making. There are also web tools in various social sites to help users knowledge-base their usage of the social net to maximize output for a certain purpose [2][7]. Though useful for a period of time, most of the sites provide publishing platforms. For instance, in Facebook, there are plugins that allow users to post something on Twitter. Analytics, coupled with broadcasting have enabled sites such as ping.fm to add analysis tools, hence differentiating themselves. These work together with seismic, to produce the best results. There are also other web analytics tools used by e-commerce sites that do not properly analyze users' opinions and sentiments. However, these have been improved by enhancing their capabilities to con- 
nect to social-media analytics that collect user information that relates to products and various brands. They also collect trends, including competitors' insights [7].

There are several social media sites whose success is not determined much by their technology parameters, but rather by their users base. LinkedIn, Twitter, Facebook and YouTube, are among such social sites that have the most contributing and engaged audiences. Years back, people would take much pride if they had many follows in Facebook and Twitter. Things have changed today, and instead, marketers have targeted certain categories of followers whereby they post content that is of interest to those and this helps to keep the followers engaged [8,9]. Users have also learned the art of attracting friends intelligently. Since people can access large amounts of data, they are no longer very much interested in public image. On the contrary, they want in-depth material. Regarding content, people consistently seek out for comprehensive material, since they are empowered [1][7]. Business intelligence helps to engage and to nurture consumers, as this is what they expect, as well. They want to be part of the product/brand, and not to simply purchase. Big data is obtained from the social networks, configured and then delivered through various programming interfaces. There are also available tools that help to format data from one form to another [10,11].

Tagged based advertising is the expansion of the Facebook pages. This methodology will be useful for the organization to advertise their item, image. Tagged based advertising permits the association to tag the input of the item to their client [12]. Once the tag has been done then this tag will then be obvious to the Friend List of the client in the News Feed. The advantage of the tag based promoting is: when an organization takes input about any item from the shopper and with his/her authorization, the criticism is tagged on the purchaser profile. This tag will now be visible in the News Feed of the Friend List of the shopper, which helps in the powerful showcasing; trust of the item will be expanded in the buyer's circle by purchaser's impact. This is the roundabout promoting that the association would be doing with minimal effort when contrasted with the other advertising media. The significant advantage of this advertising is the trust of the item which is critical in today's aggressive business sector. A sample from Kuwait would be Social Media Consulting Agency Ghaliah Tech which was established in 2011, with the reason for serving businesses or individuals trying to connect and promote their brand/image across online networking platforms. The agency offers services such as brand creation, online networking accounts administration, web promoting, web improvement, among others. Such organizations would not have existed without the emergence of online networking, and this is only one sample of the many organizations and jobs that were made possible by the social technology.

Viral marketing is well known as a word of mouth way of passing messages or information. As a marketing strategy, the study has focused on showing how communication among friends in social media such as Facebook, Twitter, YouTube, and Instagram among others, has been utilized heavily to market products as it facilitates the spread of "word of mouth" direct and indirect marketing. Branding in practice and philosophy is facing significant challenges due to the rise of digital and social media platforms that ease and allow electronic "Word of mouth". Many scholars $[3][8][9][11]$ emphasize the opportunities and benefits that online social networking 
could offer to companies. In recent times, critical research has stressed that even strong brands are open to these new environments because of the greater transparency, consumer empowerment, and online activism. IBM managers, for instance, reportedly believe that the social media communications of employees to be an enterprise-level threat, and have worked to teach employees as to corporate policy in this regard. Social media are playing important roles in political campaigning and shaping competition in which reputational factors could make the difference between success and failure.

From a customer perspective, social media has facilitated for the shift of power from the business to the consumer. This has become possible due to several different variables. Firstly, increased competition has led to increased options for consumers who have become more educated, more aware, due to the higher and better access to knowledge and feedbacks that are available on social media platforms. This has led not only for competitors to offer better products and services to consumers, but also, it has also led to product reengineering through involving the consumer in the product development process through customization, and customer interactions on social platforms. One such example of involving the customer in the product development process is the Lay's marketing campaign on social media platforms where consumers are asked to vote for their favorite potato chips flavor using hash tags on social media platforms, where the most voted for chips flavoring will be developed, and sold in the Middle East and North Africa markets.

Another example of the shift in power from businesses to consumers is while in the past negative customer experiences and complaints would sit idly in complain boxes at the business headquarters, or are not taken seriously or even ignored by the business, nowadays, the higher transparency and wider reach of social media networks means that negative experiences are not hidden from other customers. Furthermore, bad news travels faster today across social platforms to reach larger audiences. One specific example is the "United Broke my Guitar" incident where a Canadian musician's guitar at Chicago O'Hare airport was destroyed by United cargo staff, leading the musician to complain to the customer care unit and ask to be reimbursed in full, and when the musician tried to resolve the issue peacefully, but United Airlines failed to reimburse him in full. He decided to utilize the power of social media to get his voice heard, by creating a song which went viral thanks to the power of social media, reaching millions of viewers around the world, and leading United to lose $10 \%$ of their share value, which is equivalent to $\$ 180 \mathrm{M}$ USD [15]. This example shows that consumers, no matter who they are, or how small they are, can have their voices heard loud, owing that to the power of social media.

Due to the fact that customers can access information regarding most of the products and businesses they have taken interest on, they have become more informed and hence more selective and aware. It is essential not to ignore the fact that customers will communicate to others when it comes to social media. Social media marketing has caused increased customer awareness and product knowledge among customers and has hence enhanced the decision making process for the consumer. In the past, marketers held the power to influence product awareness and thus influencing product sales. The marketers based it on the purchase funnel. This divided product purchase 
into three stages. The first stage involved product awareness, followed by a mental note to purchase the product, and finally, purchasing of the product. This has greatly changed due to the impact of the social media. This change involves the effect of comments from other users regarding the subject in question. People will tend to use the product that has been proposed to them by others. Social media marketing has taken the role of creating consumer awareness from the marketer and entrusted that role to the consumer himself. The modern day consumer has the ability to research on a commodity instead of relying on the information provided by the marketer.

We now discuss how social media has promoted the creation of a new level of global understanding among cultures. Due to the advancements in telecommunication technologies, people have become more interconnected than ever before. Social media has contributed significantly to that by "bridging the gap" that existed not only among cultures, but between people and businesses as well. To elaborate, social media has added a human element to organizations [12][16]. More people nowadays perceive a business as an individual due to the interaction taking place between the business and the individual on a daily basis, regardless of whether a business transaction occurs or not - something which would have been unthinkable a decade ago. Furthermore, social media has bridged the gap by being available to both customers and businesses anywhere, any time - something again which would have been unthinkable a decade ago.

In addition, social media has bridged the gap through creating a unified language for everyone to use regardless of their race, nationality, origin or background. Such language includes symbols of affection such as likes, and thumbs ups, and symbols of dissatisfaction such as dislikes, and thumbs downs, along with symbols of approval and common interests such as hash tags and/or retweets as signs of agreement. The bottom line is that social media has bridged the distance, time, and culture gaps which have led to a flatter, more engaged, better connected and interacted world, not only among individuals themselves, but also between individuals and organizations alike [17].

From a Customer Relationship Management (CRM), social media has created a new medium for customers to express their feelings, frustrations, experiences, ask questions, and simply send and receive feedback to the organization. Moreover, social media engagement by organization can lead to the better development of the organization's Customer Relationship Management system, as it allows the organization to build up on its existing CRM software. This can be done through enhancing the customer database via low cost techniques thus allowing the business to access customer social media patterns, activities and interests, who they follow, what they post about. This allows the business to understand what can be created to satisfy current customers, and possibly attract new ones, along with allowing the organization to view what their competitors are offering to their customers, and what can be offered to pull away those customers from the competition [4][9].

In fact, taking a close look at the revenue figures of the top social networking companies gives a clear indication of the scale and volume of how popular those are to businesses embracing the services, tools and facilities of the social networks. Even further, it is evident that those social networks have themselves practically and tangi- 
bly become businesses that boost profits competing with that of the largest business enterprises in the world. Table 1 is plainly one evidence of many found in the literature as to the size of such social businesses [21].

Table 1. Comparing both the revenue and revenue per employee in 2012 ([21])

\begin{tabular}{|l|l|l|l|}
\hline Company & $\mathbf{2 0 1 2}$ Reported Revenues & Employees & Revenue Per Employee \\
\hline Facebook & $\$ 5,089,000,000$ & 4,619 & $\$ 1,101,753$ \\
\hline Zynga & $\$ 1,281,267,000$ & 2,916 & $\$ 439,391$ \\
\hline Twitter & $\$ 350,000,000$ & 900 & $\$ 388,888$ \\
\hline Automattic (WordPress) & $\$ 45,000,000$ & 150 & $\$ 300,000$ \\
\hline LinkedIn & $\$ 972,309,000$ & 3,458 & $\$ 281,176$ \\
\hline Groupon & $\$ 2,330,000,000$ & 10,000 & $\$ 233,000$ \\
\hline LivingSocial & $\$ 536,000,000$ & 4,500 & $\$ 119,111$ \\
\hline Yelp & $\$ 137,600,000$ & 1,214 & $\$ 113,344$ \\
\hline Tumblr & $\$ 13,000,000$ & 151 & $\$ 86,092$ \\
\hline Foursquare & $\$ 2,000,000$ & 100 & $\$ 20,000$ \\
\hline
\end{tabular}

\section{Prospects and Recommendations-The Good, the Bad and the Ugly}

After discussing the different effects social media has made on the business environment, we will answer the question raised earlier in this paper, and that is whether companies can survive without social media, followed by a recommendation on how companies can best utilize social media to enhance their image, generate higher profits and achieve higher customer satisfaction and hence loyalty.

All the above stresses the fact that social networks have promoted the emergence of social business networks which brings to the front the main question businesses are often confronted with and that is "To Social Media or not to Social Media". From a personal perspective, the benefits of utilizing social media by organizations greatly outweigh any negatives of social media usage. This again is due to several reasons already presented in this paper such as wider and faster reach, better cost savings, and higher customer satisfaction, among others. However, this only applies to industry specific organizations such as organizations that are highly customer centric such as 
the services industry. So yes, organizations with high customer focus must utilize social media in order to survive. That being, organizations with very low, to nonexistent customer focus such as B2B organizations do not essentially require the utilization of social media to survive.

As a consequence of the induced electronic "word of mouth", there is a growing emphasis on reputation management and reputation risk assessments in brand management. It is noted in $[17,18]$ that there is a shift in power in the relationship between marketers and online consumer networks whereby transparency impact has grown, suggesting more consumer criticism and selectivity towards brands. Latest contributions suggest that there is an urgent need for a rapprochement between branding and reputation management perspectives in the utilization of social media, as noted in [5] and [11]. Moreover, there is a growing interest in the role of corporate reputation, reputation fostering, and reputation management in organizations. Social media have received an increasing attention in the branding and marketing literature. There is a lack of practical studies and theoretical elaborations exploring the company's reputation management maneuvers under the influence of social media. Reputation management is an issue that is gaining growing importance and hence companies must invest resources to work on the development of effective electronic systems to handle that issue while integrating such systems with social networks. This is not optional any more in today's business markets.

We now move into presenting the main recommendations pertaining to the integration of social media into the business operations of any organization. These go as follows:

- Social media is not to be employed as a replacement to traditional media but should rather be used as a supplement to it. Though large is the reach of social media, it does not reach all customer segments, as some segments are still loyal to traditional media, so it is recommended to utilize them concurrently. This especially applies to the older generations.

- Despite the current emphasis placed on social media platforms by some organizations, it should be emphasized that this does not take away the importance of traditional face-to-face interaction [19], as that is equally important. As such, a balance must be formulated between the organizations "intangible" social media persona, and the organizations "tangible" real life persona.

- Social media is often used to mislead customers through unrealistic advertisements, false promises, buying followers, while it should be the case that the quality of, rather than the quantity, of the customers is what needs to be quantified.

- It must be stressed that social media is a cost saving tool, and organizations should not make it a costly platform through excessive and exaggerated pricing for online promotions and campaigns.

- Organizations should avoid taking advantage of the free nature of social media and abuse it by excessive overloaded postings.

- Social nets have reshaped the concept of online reputation systems. Many organizations are trying to develop social media policies in order to protect their reputation as social media problems emerge. Insurance coverage designed to provide re- 
sources in instances of reputational damage (including online mishaps) have been formulated [1].

- Social networks have proven to be a useful tool in investment and entrepreneurship. This has created a considerable impact on entrepreneurships worldwide in relation to social media as an effective marketing tool. These effects can be seen in relation to its effect on cost, organization, objectives and marketing strategies. Strategies have evolved to include business networks-related goals and rules.

- Social marketing is seen to be the future of marketing. This can be determined from the rate at which it is being embraced in the corporate world and the importance accorded to it [20]. Its popularity is rising fast such that there are social media marketing companies on the rise. However, it is imperative to note that the success of any social media marketing project is based on proper planning and evaluation of the target market. This can be done by following the steps outlined below:

a) Carefully analyse the effects of social media marketing on the business in order to determine whether the business is capable of absorbing any problems or burden related to the integration of social networks as a marketing tool.

b) Analyse the social networks with the aim of finding the most suitable one for the desired target customer segment.

c) Ensure that educated, specialized, and experienced personnel are assigned for handling the use of the media.

d) Choose the best way to manage your social media channel or channels in case you opt for different social media platforms.

e) Set up a strategy by which you will be operating after setting up the social media channel. This will also include business rules associated with the use of such channels.

f) Find the optimal manner to interact with the target group. Finding the best content through which you can keep your target group keeping up with the social media channel developed.

g) Establish a means through which a business can profit from the social media channel. This means developing the ability to distinguish between socializing and marketing. The latter should be the main target.

h) Carefully allocate time for managing the social media channel.

- Due to the diversity of users of the social networks who come from different education levels, backgrounds, ages, interests and experiences, the use of such media is mostly time consuming and distracting. Dedicated staff, with time management skills, must be appointed to handle the influx of postings and to manage the platform.

We now briefly shed some light on the ugly ingredients and repercussions of social networking. 
- Piracy", "Cybercrimes", "Cyberbullying", "Cyber-stalking”, "Child safety”, "potential for misuse", "unauthorized access", lack of physical interaction, and the psychological and behavioral consequences of social overload are global challenges that communities are facing today. It is very hard to take something back once it is posted, even if it gets deleted [9]. The response has to be both careful and expeditious. Otherwise it is quite useless to respond at all postings and could be damaging.

- Burden of the marketing shift induced by the new trends pose new challenges of carefully formulating customer relationships that focus on inviting customer involvement. Companies have to develop stories that promote the culture of the product instead of simply outlining its particular benefits.

- Customer empowerment is one of the burdens placed on the businesses. Disappointments travel quickly to the friends' circles and eventually to wider circles of networkers.

- Accidental postings of improper statements will create a long lasting effect and cannot be retracted.

- Starting wrong without proper adequate research and preparation will likely be fatal and backtracking might be very costly.

- "Social Media is Creating Bad Customers", a post published by Jeff Wilson, Partner/Chief Customer Experience Designer at Sensei Marketing, that is sparking discussion among digital marketers. In the post, Wilson argues that social media equips the average person with four "factors empowering bad behavior, particularly against companies:" (1) No Guilt (2) The Mob (3) Relative Anonymity and (4) No Accountability. "If anything, social media has increased the importance of building positive customer experiences online and off". This view is correct especially if the social media is the only or main source the public derives feedback from. The questions he suggests businesses ought to consider are important: "What are the risks?" and "What is the compelling reason for you to use social media? If it is because competitors are using it, this is not good enough reason.

\section{Conclusion}

Social media has, today, become a parcel of the business ecosystem, rather than a separate isolated entity. Businesses need to integrate social networking with their business processes. Social networking can fundamentally help change the business. Social media offer interaction over the web as it offers content that is user-generated. Through the social media, a modern cultural infrastructure is formulated, which is more responsive to customer behaviors. This interaction has become very interlinked with organizational processes, leading to Enterprise Social Marketing (EPM). Social media and EPM allow for authenticity, increased granularity, improved responsiveness, value creation, proper targeting, analytics, and flexibility.

Social media has transformed the business world, from bridging the gap with the customers, to higher marketing cost savings, to better damage control, to higher customer satisfaction, to greater lead generation, among many others. Moreover, social 
media although available to all organizations, can create a competitive advantage for the organizations that know how to best utilize it, and this competitive advantage is the fine line between success and failure in today's highly competitive global business environment.

To understand the full impact of social networks, they need to be addressed from the perspectives of both the business and the customer. This paper has done so and presented some highlights and guidelines that users often disregard or undermine. Such media is a tool for maintaining a good customer relationship though the effect could be detrimental, if misused. It also can be a useful platform for globalizing a business or a brand name. Quite a large number of businesses have recognized the fact that social or, more appropriately, business networks have also developed to be a reputation management tool that can promote the reputation of the organization or otherwise, if mismanaged.

Given the fact that this paper has shown how social networks have actually transformed into business social networks, embracing the integration of such networks into the core business processes has become more than a luxury if a business needs to be constantly connected to its customers as well as suppliers, and to the public at large. The adoption however needs to be done carefully and for this a list of recommendations has been presented, taking into account some precautions.

\section{References}

1. Kaplan, M. and Haenlein, M.: Users of the world, unite! The challenges and opportunities of Social Media, Business Horizons, 53(1) (2010)

2. Livingstone, S.: Taking risky opportunities in youthful content creation: teenagers' use of social networking sites for intimacy, privacy and self-expression, J. New media \& society, 10(3). pp. 393-411 (2008)

3. Mohammad, Y. A.. Integration of social media in businesses: International Journal of Business and Social Science, 5(8) (2014)

4. Rodriguez, M., Ajjan, H., and Peterson, R. M.: CRM/Social media technology: Impact on customer orientation process and organizational sales performance. Journal of Marketing Development and Competitiveness, 8(1), 85-97 (2014)

5. Constantin Logofatu M.: The Social Media Impact On Small And Medium Sized Businesses in Young Economists Journal / Revista Tinerilor Economisti, 9(18):214-218 (2012)

6. Pfeiffer M, Zinnbauer M. Can Old Media Enhance New Media? How Traditional Advertising Pays off for an Online Social Network: Journal Of Advertising Research, 50(1):42-49 (2010)

7. Laroche M, Habibi M, Richard M.: To be or not to be in social media: How brand loyalty is affected by social media?, International Journal Of Information Management, 33(1):76-82 (2013)

8. Andzulis, J, Panagopoulos, N, and Rapp, A.: A Review of Social Media and Implications for the Sales Process, Journal Of Personal Selling and Sales Management, 32(3), pp. 305-316 (2012) 
9. Chau, M, and Xu, J.: Business Intelligence In Blogs: Understanding Consumer Interactions And Communities, MIS Quarterly, 36(4), pp. 1189-1216 (2012)

10. GOI, C.: The Impacts of Social Media on the Local Commercial Banks in Malaysia, Journal Of Internet Banking and Commerce, 19(1), pp. 1-10 (2014)

11. Harrysson, M, Metayer, E, and Sarrazin, H.: How 'social intelligence' can guide deci sions, Mckinsey Quarterly, 4, pp. 81-89 (2012)

12. Oh, O, Agrawal, M, and Rao, H.: Community Intelligence And Social Media Services: A Rumor Theoretic Analysis Of Tweets During Social Crises, MIS Quarterly, 37(2), pp. 407-A7 (2013)

13. Rohan, M.: Social media and its implications for viral marketing. Asia Pacific Public Relations Journal, 11(1), pp. 1-3 (2011)

14. Recine, M, Prichard, J, and Chaudhury, A.: Social Media and Evolving Marketing Communication Using IT, Communications Of The Association For Information Systems, 33, pp. 115-128 (2013)

15. Singh, N.: Social Media and Corporate Agility, Global Journal Of Flexible Systems Management, 14 (4), pp. 255-260 (2013)

16. Bronstein, J. and Aharony, N.: Personal and political elements of the use of social networking sites, Information research, 20(1) (2015)

17. Boyd, D. M. and Ellison, N. B.: Social Network Sites: Definition, History, and Scholarship, Journal of Computer-Mediated Communication, 13(1) (2007)

18. Cabot, J.E.: The information age; Manuel Castells; the rise of the network society, Research Policy, 32(1141) pp. 57-68 (2003)

19. Chauhan, S.: Factors Affecting Use of Mobile Social Networking, Vilakshan, XIMB Journal of Management, 11(1) (2014)

20. Men, L.R. and Tsai, W. H.: Toward and Integrated Model of Public Engagement on Corporate Social Networking Sites: Antecedents, the Process, and Relational Outcomes, International Journal of Strategic Communication, 7(2), pp. 257-273 (2013)

21. http://www.web-strategist.com/blog/2013/03/18/social-networks-by-revenue-andemployees-facebook-stands-above-all/ 